OPEN ACCESS

Edited by:

Stefania Astolfi,

Tuscia University, Italy

Reviewed by:

Giacomo Cocetta

University of Milan, Italy

Alessandro Miceli,

University of Palermo, Italy

${ }^{*}$ Correspondence:

Angelo Signore

angelo.signore@uniba.it

Specialty section:

This article was submitted to

Plant Nutrition,

a section of the journal

Frontiers in Plant Science

Received: 04 February 2020

Accepted: 21 April 2020

Published: 14 May 2020

Citation:

Signore A, Bell L, Santamaria $P$, Wagstaff $C$ and Van Labeke M-C

(2020) Red Light Is Effective

in Reducing Nitrate Concentration

in Rocket by Increasing Nitrate

Reductase Activity, and Contributes

to Increased Total Glucosinolates

Content. Front. Plant Sci. 11:604.

doi: 10.3389/fpls.2020.00604

\section{Red Light Is Effective in Reducing Nitrate Concentration in Rocket by Increasing Nitrate Reductase Activity, and Contributes to Increased Total Glucosinolates Content}

\author{
Angelo Signore ${ }^{1 *}$, Luke Bell ${ }^{2}$, Pietro Santamaria ${ }^{1}$, Carol Wagstaff ${ }^{3}$ and \\ Marie-Christine Van Labeke ${ }^{4}$
}

${ }^{1}$ Department of Agricultural and Environmental Science, University of Bari Aldo Moro, Bari, Italy, ${ }^{2}$ School of Agriculture, Policy and Development, University of Reading, Reading, United Kingdom, ${ }^{3}$ Department of Food and Nutritional Sciences, University of Reading, Reading, United Kingdom, ${ }^{4}$ Department of Plants and Crops, Faculty of Bioscience Engineering, Ghent University, Ghent, Belgium

Rocket cultivation is increasing to supply the expanding ready-to-eat market because of its unique taste, but crops are often over fertilized to avoid nitrogen deficiencies. This leads to nitrate accumulation in leaves, and the products of their degradation (nitrites and nitrosamines) have been related to several health problems. Nitrate concentrations in rocket and other leafy vegetables are subject to limits by the EU legislation, yet rocket holds a great nutritional value. Degradation products of glucosinolates (isothiocyanates) have been consistently linked with benefits to human health. We investigated the influence of nitrogen application (1 and $8 \mathrm{mM}$ ), species [Eruca sativa (L.) Cav. and Diplotaxis tenuifolia (L.) DC.] and light spectrum (full spectrum, red, blue and red + blue) on the nitrate concentration, nitrate reductase activity and glucosinolate content of rocket grown in a soil-less system. Red light decreased the nitrate concentration with respect to the blue spectrum $\left(4,270\right.$ vs. $7,100 \mathrm{mg} \cdot \mathrm{kg}^{-1}$ of fresh weight, respectively), but such reduction was influenced by the species and the nitrogen level (significantly higher in $D$. tenuifolia and with the higher concentration of $N$ ). The nitrate reductase activity increased under red light in $D$. tenuifolia, with the lower $N$ concentration. Rocket is known to contain several health-promoting compounds mainly antioxidants and glucosinolates, as secondary metabolites that act as part of plant defense mechanisms. The total content of glucosinolates was mainly affected by the species $(D$. tenuifolia showed the highest concentrations). Our results will help growers to tailor light spectra with the aim of reducing nitrate concentration and to remain within EU legislative limits, without any detrimental influence on other qualitative parameters in rocket.

Keywords: Eruca sativa, Diplotaxis tenuifolia, soilless culture, glucosinolates, light emitting diodes 


\section{INTRODUCTION}

The name "rocket" (or rucola, arugula, and roquette) is a collective term to indicate several species of the Brassicaceae family, indigenous to the Mediterranean region, whose leaves are characterized by a pungent taste, that are used to flavor salads. Four species are used for human consumption, namely Eruca sativa (synonym Eruca vesicaria; salad or cultivated rocket), Diplotaxis tenuifolia (wild or perennial rocket), Diplotaxis muralis and Diplotaxis erucoides, but only the former two are cultivated on a large scale (Bianco et al., 1998; Bell and Wagstaff, 2014). Leaves are typically sold in salad bags (mixed or alone) and their commercial importance has increased significantly across the globe. Indeed, even though rocket has been consumed since ancient times (Hall et al., 2012), it was still considered as an underutilized species until 20 years ago (Bianco, 1995). As with many Brassicaceae species, rocket has a high concentration of compounds with beneficial aspects for human health, such as glucosinolates (GSLs), flavonols and vitamin C. For such a crop, there are also reports that leaves have diuretic and anti-inflammatory properties, as well as beneficial cardiovascular effects (Mahran et al., 1991; De Feo and Senatore, 1993; D’Antuono et al., 2008; Egea-Gilabert et al., 2009; Björkman et al., 2011).

Rocket species are known to be a hyper-accumulators of nitrate (Santamaria et al., 1998a). Nitrate is considered harmful for human health when present in high concentrations, as an anti-nutritional dietary component. Through its reduction to nitrite and conversion to nitrosamines in vivo, it has been linked with methemoglobinemia and cancer (Santamaria, 2006). Nitrate has been linked also with positive health aspects, such as cardioprotective properties (Bondonno et al., 2016). The picture relating to its health effects is therefore subject to much debate.

The ability of rocket to hyper-accumulate nitrate, and in particular in D. tenuifolia (Santamaria et al., 2002), is so high that the acceptable daily intake (ADI) could be exceeded by eating less than $50 \mathrm{~g}$ rocket with a median nitrate concentration (European Food Safety Authority, 2008). In recent years, the harmfulness of nitrate has been disputed, and there are some studies that have proposed that nitrate has to be considered as a nutrient necessary for health, rather than as a contaminant which needs to be restricted. Such studies have debated, for example, the function of nitrate with respect to blood pressure and cardiovascular health (Bondonno et al., 2016; Jonvic et al., 2016; Ashworth and Bescos, 2017), and the significant reduction of oxygen consumption and higher total muscle work during moderate-intensity exercise (Porcelli et al., 2016).

Despite the lack of scientific consensus, the European Commission [with the Regulation (EC) N. 1258/2011, European Commission, 2011; amending Regulation (EC) N. 1881/2006] has arbitrarily set maximum levels for nitrates $\left(\mathrm{NO}_{3}{ }^{-}\right)$in foodstuffs, including rocket (for which the limits are 6,000 and 7,000 mg $\mathrm{NO}_{3}{ }^{-} \cdot \mathrm{kg}^{-1}$, if harvested between 01 April to 30 September and from 01 October to $31 \mathrm{March}$, respectively). These limits cannot be legally exceeded, and product in breach of the regulations cannot be sold in the EU.
The factors influencing nitrate accumulation in vegetables are numerous; for example the species, the organ that is consumed (with leaves and petioles playing a major role), the fertilization and light intensity (Santamaria, 2006; Weightman et al., 2012). Among the above factors, the most important ones are nitrogen availability and light intensity. With regard to nitrogen fertilization, there are some strategies that can be used for reducing the nitrate content; in particular in hydroponic systems (Santamaria et al., 1998a,b).

It has been demonstrated that nitrate accumulation is higher with low light intensity (Premuzic et al., 2002). This could lead to major problems, particularly in northern European countries, in which the light intensity is usually lower than the southern countries. But even in the latter ones, if dull conditions and high temperatures persist the days before the harvest, nitrate concentrations can be increased (Weightman et al., 2012). Under these conditions nitrate becomes an important anion osmoticum due to a lower carbon source flux (Seginer, 2003); but also nitrate reductase activity influences the nitrogen flux (NR; the enzyme converting nitrate to nitrite prior to its assimilation into ammonium, amino acids and, as latest step, proteins) as it is activated by light (Weightman et al., 2012). Low light intensity may therefore induce a higher nitrate content (Santamaria, 2006).

With respect to light, greenhouse growers can influence light intensity through supplementary lighting, while such technique is hardly applied in soil-bound production. Moreover, the use of LED lights is increasing in rocket production as it allows cultivation in closed or semi-closed environments, and an ability to modify plant secondary metabolism (Ouzounis et al., 2015) to favor the accumulation of substances useful for human health. However, the influence of light spectra is various, and depends on several parameters. For example, Bian et al. (2018) underlined the importance of green light on nitrate reduction in lettuce, while others (Viršilë et al., 2019) found that a mix of red and blue light decreased nitrate but increased nitrite concentrations on tatsoi. In addition, the effect of light spectra on nitrate concentration has been demonstrated to be genotype dependant (Viršilë et al., 2020).

Given the above premises, the scope of our work was to compare the effects of four light treatments (Full Spectrum, FS; BLUE, RED, and RED + BLUE) on two species of rocket grown with two levels of nitrogen $\left(\mathrm{N}-1\right.$ and $\left.8 \mathrm{mmol} \cdot \mathrm{L}^{-1}\right)$ in nutrient solution (NS), and their effects on NR activity, yield, nitrate concentration and GSLs in the leaves.

\section{MATERIALS AND METHODS}

A trial was carried out in controlled environment growth chambers located at the Department of Plant and Crops, Ghent University (Belgium).

\section{Plant Material and Experimental Setup}

Seeds of rocket (E. sativa and D. tenuifolia) were sown into rockwool plugs (diameter $2 \mathrm{~cm}$, height $2.7 \mathrm{~cm}$ - Grodan BV, Netherlands) soaked with tap water, which electric conductivity was $0.5 \mathrm{dS} \cdot \mathrm{m}^{-1}$, and arranged into polystyrene trays. The sowing 
was done on January 29 and the entire cycle (from sowing to harvest) lasted 66 days. Subsequently, the rockwool plugs were covered with wetted vermiculite and the trays were covered with a transparent plastic film, to avoid humidity loss until complete germination. Germination took place in a dark chamber (temperature: $20^{\circ} \mathrm{C}$ ) for 3 days. Thereafter, the plastic film was removed and the trays were moved onto an aluminum bench, under artificial light (high pressure sodium lamps - SON-T, 400 W, Philips, Eindhoven, Netherlands) with a light intensity (at canopy level) of $200 \mu \mathrm{mol} \cdot \mathrm{m}^{-2} \cdot \mathrm{s}^{-1}$ and a photoperiod of $14 / 10 \mathrm{~h}$ (day/night). The plants were irrigated with tap water, four times a day, through an ebb-and-flood system.

Four days after the germination, the fertigation started (see section "Nutrient Solution" for the NS composition and management). The NS concentration was $1 / 4$ of the final concentration for the first 10 days, and then $1 / 2$ of the final concentration for the following 4 days. Subsequently the plants were transplanted, at the second true leaf stage, into polystyrene boxes, whose internal measures were 23,27 , and $11 \mathrm{~cm}$ for length, width, and height, respectively, which available volume, after a waterproof coating with plastic, was equal to $5.5 \mathrm{~L}$, containing the NS (nutrient composition reported in Table 1). Each box held five rockwool plugs, and each plug contained four and eight plants for E. sativa and D. tenuifolia, respectively. Twenty-one days after the transplant, the treatments were differentiated with respect to the nitrogen concentration and the light spectrum. The experimental design used was a split-plot design over sites, with the main factor (sites) represented by the light treatment. In every light treatment, corresponding to one bench containing the boxes, the nitrogen concentration was the main plot and species were the subplot factor. Every treatment was replicated three times.

\section{Nutrient Solution}

The NS was prepared by using lab salts (purity $>99 \%$ ), with the exception of iron, for which Sequestrene 138 Fe 100 SG

TABLE 1 | Levels of the macro and microelements into the nutrient solutions.

\begin{tabular}{lcc}
\hline Macroelement & \multicolumn{2}{c}{$\mathbf{N}$ level (mM) } \\
\hline & 1 & 8 \\
\hline & \multicolumn{2}{c}{ Element concentration (mM) } \\
\hline $\mathrm{N}$ & 1.00 & 8.00 \\
$\mathrm{P}$ & 4.37 & 4.39 \\
$\mathrm{Mg}$ & 1.32 & 1.32 \\
$\mathrm{Ca}$ & 1.22 & 1.22 \\
$\mathrm{~S}$ & 2.64 & 4.65 \\
\hline
\end{tabular}

Microelement Element concentration $(\mu \mathrm{M})$

\begin{tabular}{lc}
\hline $\mathrm{Fe}$ & 20 \\
$\mathrm{Cu}$ & 0.5 \\
$\mathrm{Zn}$ & 2 \\
$\mathrm{Mo}$ & 0.1 \\
$\mathrm{Mn}$ & 5 \\
$\mathrm{~B}$ & 25
\end{tabular}

(Syngenta, Oosterzele, Belgium) was used. The NS used differed for nitrogen concentration (1 or $8 \mathrm{mmol}$ - Table 1). Every day, if needed, fresh NS was added to the boxes. The $\mathrm{pH}$ value of the NS was maintained in the range $6-7$ by adding $\mathrm{HCl}$ ( $1 \mathrm{M}$; as required) while the EC value were 1.20 and $1.65 \mathrm{dS} \cdot \mathrm{m}^{-1}$ for the nitrogen concentration of 1 and $8 \mathrm{mM}$, respectively. The oxygenation of the NS was provided continuously by a compressor connected to plastic pipes that were submerged into the NS.

\section{Light Treatments}

Four light treatments were set up, namely: FS (full spectrum by the means of a solid state plasma light - Gavita Holland, Aalsmeer, Netherlands), blue (BLUE, peak at $460 \mathrm{~nm} \mathrm{-}$ GreenPower LED research module, Philips, Eindhoven, Netherlands), red (RED, peak at $660 \mathrm{~nm}$ - GreenPower LED production module), as well as a combination of red with blue $(\mathrm{R}+\mathrm{B}, 75 \%$ red $+25 \%$ blue $)$ with a programmable LED experimentation system (CI-800, CID Bio-Science, Camas, WA, United States), respectively. Light intensity was $150 \mu \mathrm{mol}$ $\mathrm{m}^{-2} \mathrm{~s}^{-1}$ at canopy level, which results in a daily light integral of $7.5 \mathrm{~mol} \mathrm{~m}^{-2}$.

\section{Harvesting and Sampling}

The harvest was performed manually by cutting the plants with scissors ( $1 \mathrm{~cm}$ above the box level) and by immediately weighing the material to determine the fresh weight. Of the fresh material, a quota of stems and leaves (a balanced mix of apical, median and basal zone) was immediately ground in liquid nitrogen (IKA ${ }^{\circledast}$ A11 Basic Analytical Mill, Germany) and the resulting powder was stored at $-80^{\circ} \mathrm{C}$ for the NR assay and for the determination of GSL content. Subsequently, a quota of the fresh weight (around $20 \mathrm{~g}$ ) for every replication was placed into a ventilated oven at $65^{\circ} \mathrm{C}$, until its weight was constant, for the dry matter determination. Afterward, material was ground to a powder for the analysis of nitrates in the tissues.

\section{Analytical Determinations Leaves NR Assay}

Leaves $(1 \mathrm{~g})$ were ground in a chilled mortar with $2 \mathrm{~mL}$ of extraction buffer as described previously by Reda (2015). The crude supernatant was used for the measurement of NR in the absence of $\mathrm{MgCl}_{2}$ (total activity $-\mathrm{NR}_{\text {total }}$ ) and/or in the presence of $\mathrm{MgCl}_{2}$ (actual activity - $\mathrm{NR}_{\mathrm{act}}$ ).

The reaction medium contained $50 \mathrm{mM}$ Hepes- $\mathrm{KOH}, \mathrm{pH}$ 7.5, $5 \mathrm{mM}$ EDTA $\left(\mathrm{NR}_{\text {total }}\right)$ or $5 \mathrm{mM} \mathrm{MgCl}\left(\mathrm{NR}_{\mathrm{act}}\right), 10 \mathrm{mM}$ $\mathrm{KNO}_{3}$ and crude extract. Following the addition of $0.2 \mathrm{mM}$ $\mathrm{NADH}$, the reaction was carried out in a heated water bath at $27^{\circ} \mathrm{C}$ for $5 \mathrm{~min}$ and then stopped with $0.066 \mathrm{~mL}$ of $1 \mathrm{mM}$ zinc acetate. The mixture was centrifuged $\left(18,000 \mathrm{~g}\right.$ for $18 \mathrm{~min}$ at $\left.4^{\circ} \mathrm{C}\right)$ and the nitrite concentration was determined colorimetrically at $540 \mathrm{~nm}$. The activation state of NR was calculated as the ratio $\mathrm{NR}_{\mathrm{act}} / \mathrm{NR}_{\text {total }}$ activity expressed as a percentage.

\section{Nitrate Analysis}

Nitrate concentrations were determined by ion chromatography (Dionex model DX500; Dionex Corporation, Sunnyvale, CA, United States) with a conductivity detector, using the pre-column 
IonPack AG14 and the column of separation IonPack AS14 (Signore et al., 2008). Ultrapure water at $18 \mathrm{M} \Omega / \mathrm{cm}$ (Milli-Q Academic Millipore) was used in all the analysis.

\section{Glucosinolate Extraction and Analysis Reagents and chemicals}

All solvents and chemicals used were of LC-MS grade and obtained from Sigma-Aldrich (Poole, United Kingdom) unless otherwise stated.

\section{Glucosinolate extraction}

The extraction protocol used was taken from Bell et al. (2015). Briefly, two experimental replicates of each biological rep $(n=6)$ were prepared as follows: $40 \mathrm{mg}$ of ground powder was heated in a dry-block at $75^{\circ} \mathrm{C}$ for $5 \mathrm{~min} ; 1 \mathrm{~mL}$ of preheated $70 \%(\mathrm{v} / \mathrm{v})$ methanol $\left(70^{\circ} \mathrm{C}\right)$ was then added to each sample and placed in a water bath for $20 \mathrm{~min}$ at $70^{\circ} \mathrm{C}$. Samples were centrifuged for $5 \mathrm{~min}\left(12,000 \mathrm{rpm}, 20^{\circ} \mathrm{C}\right)$ to collect loose material into a pellet. The supernatant was then filtered using $0.22 \mu \mathrm{m}$ Acrodisc syringe filters with Supor membrane (hydrophilic polyethersulfone; VWR, Lutterworth, United Kingdom) into fresh Eppendorf tubes. Samples were frozen at $-80^{\circ} \mathrm{C}$ until analysis by LC-MS.

\section{LC-MS analysis}

Immediately before LC-MS analysis, each sample was diluted with $9 \mathrm{~mL}$ of HPLC-grade water. Samples and standards were run in a random order with QC samples (Dunn et al., 2012). An external standard of sinigrin hydrate was prepared for quantification of GSL compounds. The preparation was as follows: a $12 \mathrm{mM}$ solution was prepared in $70 \%$ methanol. A dilution series of concentrations was prepared as an external calibration curve with HPLC-grade water $(112,56,42,28,14$, and $5.6 \mathrm{ng} \cdot \mu \mathrm{l}^{-1}$; sinigrin correlation coefficient $y=28.06 ; r^{2}=0.999$; Jin et al., 2009). Relative response factors (RRFs) were used in the calculation of GSL concentrations where available. Where such data could not be found for intact GSLs, RRFs were assumed to be 1.00 .

LC-MS analysis was performed in the negative ion mode on an Agilent 1260 Infinity Series LC system (Stockport, United Kingdom) equipped with a binary pump, degasser, autosampler, column heater, diode array detector, and coupled to an Agilent 6120 Series single quadrupole mass spectrometer. Separation of samples was achieved on a Gemini $3 \mu \mathrm{m} \mathrm{C18} 110 \AA$ $(150 \mathrm{~mm} \times 4.6 \mathrm{~mm})$ column (with Security Guard column, C18; $4 \mathrm{~mm} \times 3 \mathrm{~mm}$; Phenomenex, Macclesfield, United Kingdom), as recommended by Ares et al. (2014). GSLs were separated during a 40-min chromatographic run, with 5-min post-run sequence. Mobile phases consisted of ammonium formate $(0.1 \%$; A) and acetonitrile (B) with the following gradient timetable: (i) $0 \min (\mathrm{A}-\mathrm{B}, 95: 5, \mathrm{v} / \mathrm{v})$; (ii) $0-13 \mathrm{~min}(\mathrm{~A}-\mathrm{B}, 95: 5, \mathrm{v} / \mathrm{v})$; (iii) 13-18 $\min (\mathrm{A}-\mathrm{B}, 40: 60, \mathrm{v} / \mathrm{v})$; (iv) 18-26 $\min (\mathrm{A}-\mathrm{B}, 40: 60, \mathrm{v} / \mathrm{v})$; 26-30 min (A-B, 95:5, v/v); (v) 30-40 min (A-B, 95:5, v/v). The flow rate was optimized for the system at $0.4 \mathrm{~mL} / \mathrm{min}$, with a column temperature of $30^{\circ} \mathrm{C}$, and $25 \mu \mathrm{l}$ of sample was injected into the system. Quantification was conducted at a wavelength of $229 \mathrm{~nm}$ (DAD).

MS analysis settings were as follows: API-ES was carried out at atmospheric pressure in negative ion mode (scan range $\mathrm{m} / \mathrm{z}$ 100-1500 Da). Nebulizer pressure was set at $50 \mathrm{psi}$, gasdrying temperature at $350^{\circ} \mathrm{C}$, and capillary voltage at $2,000 \mathrm{~V}$. Compounds were identified using their primary ion mass and by comparing relative retention times with those published in the literature (Lelario et al., 2012). All data were analyzed using Agilent OpenLAB CDS ChemStation Edition for LC-MS (Agilent, version A.02.10).

\section{Statistical Analysis}

Treatment means were compared using orthogonal contrasts with one degree of freedom (Steel and Torrie, 1988). Three comparisons were made for light treatments: (i) Full light vs. the three light spectra (BLUE, RED, and RED + BLUE LED); (ii) $\mathrm{R}+\mathrm{B}$ vs. R, B; (iii) R vs. B. Data were subjected to the general linear model procedure (SAS Institute, Cary, NC, United States). The variance results of the main treatments, interactions and contrasts is reported in Table 2.

\section{RESULTS}

\section{Yield and Dry Matter (DM) Percentage}

Yield was not influenced by the species used, while a significant increase was produced by the nitrogen level, with $8 \mathrm{mM}$ nitrogen treatment producing $200 \%$ more crop compared to the $1 \mathrm{mM}$ treatment (Table 3). By comparing the yield obtained by the three LED spectra, RED light produced $31 \%$ more than B and $\mathrm{R}+\mathrm{B}$ (Tables 2, 3).

The DM percentage was influenced by the species, by the $\mathrm{N}$ level, from their interaction, and from an interaction between some light spectra (Table 2). In general, the $1 \mathrm{mM}$ treatment produced a significantly higher DM percentage with respect to $8 \mathrm{mM}$, and Eruca showed a higher percentage DM compared to D. tenuifolia (Table 3). The DM percentage was modulated by the light treatment, as the RED light increased the amount of DM with respect to BLUE, especially in Eruca compared to Diplotaxis (Figure 1A). Such interaction was further modulated by the $\mathrm{N}$ level, since E. sativa produced a higher content of DM under the RED treatment with the lower nitrogen level (Figure 1B).

\section{Nitrate Concentrations}

The $\mathrm{R}$ and $\mathrm{R}+\mathrm{B}$ treatments produced the lowest concentrations, while BLUE light the highest, even when the nitrate content was greatly influenced by the nitrogen concentration in the NS. The higher the nitrogen treatment, the higher the nitrate concentration (Table 2 and Figure 2A), which is what would be expected. Yet, the influence of light and $\mathrm{N}$ level on nitrate concentrations was species dependent: in the BLUE treatment in D. tenuifolia $(1 \mathrm{mM})$, the $\mathrm{NO}_{3}{ }^{-}$concentration was threefold higher than that of RED (Figure 2B); while in E. sativa (with the same level of $\mathrm{N}$ ), the nitrate content was increased only by $46 \%$ (Figure 2B). Such light-driven difference was present, in both species; also in the $8 \mathrm{mM}$ treatments, and more pronounced in E. sativa ( $>200 \%$ increase) than in D. tenuifolia (Figure 2B). 
TABLE 2 | Summary table of variance of the main treatments and interactions.

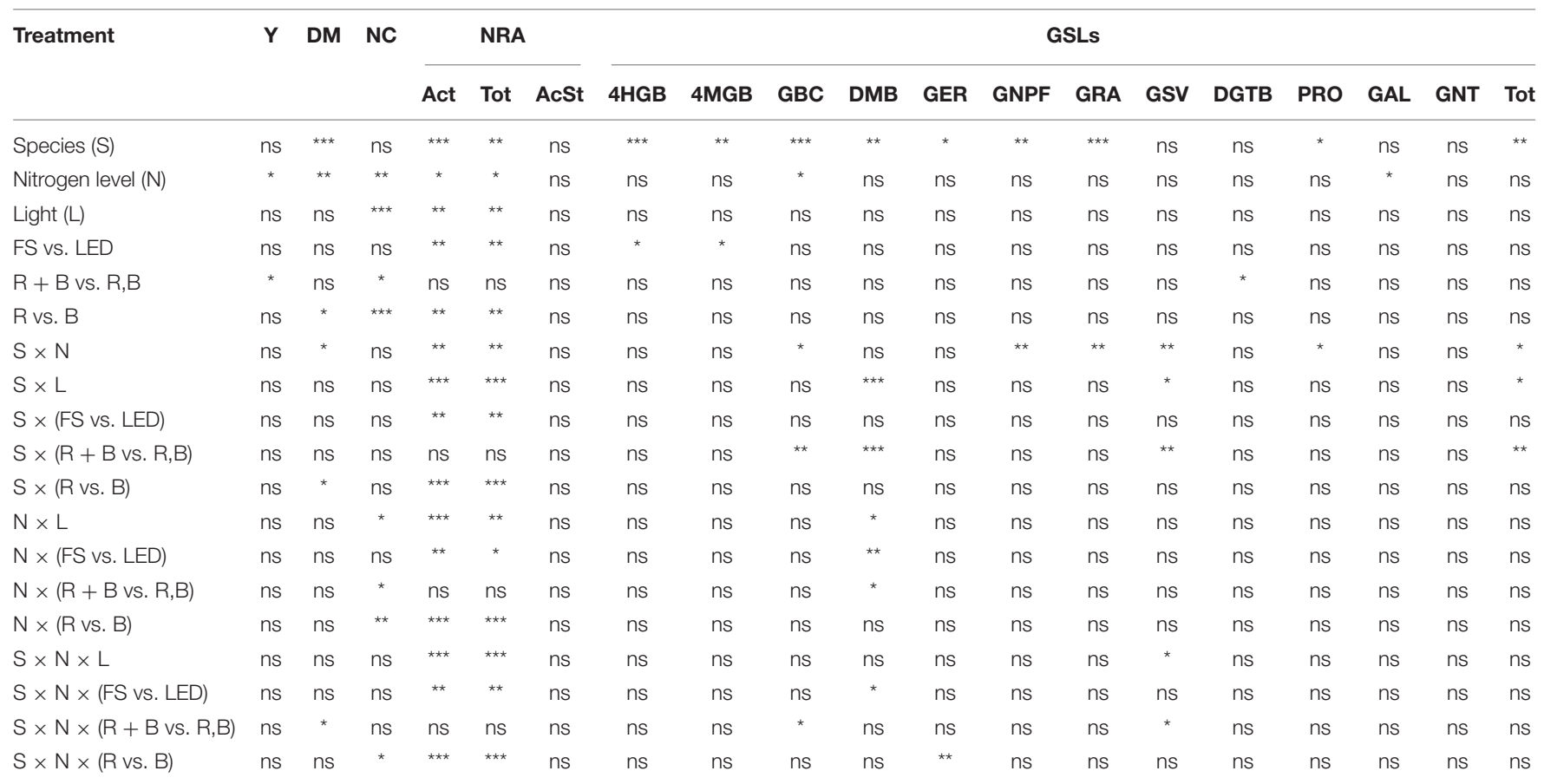

Significance of F: ns, not significant for $P \leq 0.05 ;{ }^{*},{ }^{* *}$, and ${ }^{* * *}=$ significant for $P \leq 0.05,0.01$ and 0.001. Y, yield; DM, dry Matter; NC, nitrate concentration; NRA, nitrate reductase activity; Act, nitrate reductase activity actual; Tot, nitrate reductase activity total; AcSt, nitrate reductase activity activation state; GSLs, glucosinolates; 4HGB, 4-hydroxyglucobrassicin; 4MGB, 4-methoxyglucobrassicin; GBC, glucobrassicin; DMB, dimeric-glucosativin; GER, glucoerucin; GNPF, gluconapoleiferin; GRA, glucoraphanin; GSV, glucosativin; DGTB, diglucothiobeinin; PRO, progoitrin; GAL, glucoalyssin; GNT, gluconasturtiin; GSLs Tot, total of glucosinolates). B, BLUE, peak at $460 \mathrm{~nm} ; R, R E D$, peak at $660 \mathrm{~nm} ; R+B, R E D+B L U E, 75 \%$ red $+25 \%$ blue.

\section{Nitrate Reductase Activity}

As the behavior of $\mathrm{NR}_{\text {act }}$ and $\mathrm{NR}_{\text {total }}$ has followed the same pattern as each other (Table 2), only the data of the former will be commented on by referring to it as NR activity.

The LED lights significantly increased the NR activity in comparison to the FS treatment with both $\mathrm{N}$ treatments, except for E. sativa ( $1 \mathrm{mM}$; Figure 3A), with values almost the same

TABLE 3 | Average yield and dry matter of rocket as a function of light treatment, nitrogen level and species.

\begin{tabular}{lcc}
\hline Treatment & $\begin{array}{c}\text { Yield } \\
(\mathbf{g} \text { plant }\end{array}$ & $\begin{array}{c}\text {-1) } \\
\left(\mathbf{g} \cdot \mathbf{1 0 0} \mathbf{~ g}^{-\mathbf{1}} \text { matter }\right. \\
\text { fresh weight) }\end{array}$ \\
\hline Species & & \\
Eruca sativa & 104 & 9.66 \\
Diplotaxis tenuifolia & 114 & 8.21 \\
Nitrogen level (mM) & & \\
1 & 72 & 10.28 \\
8 & 144 & 7.68 \\
Light & & \\
SL & 114 & 8.95 \\
BLUE & 99 & 8.60 \\
RED & 129 & 9.45 \\
R + B & 98 & 8.62 \\
\hline The variance results of the main treatments, interactions and contrasts are reported \\
in Table 2.
\end{tabular}

with LED or FS. D. tenuifolia had on average greater values with LED, as with $1 \mathrm{mM} \mathrm{N}$ the NR activity value was three fold higher in LED compared to FS (6.83 and $2.05 \mu \mathrm{mol} \mathrm{NO}{ }_{2}^{-} \cdot \mathrm{g}$ $\mathrm{FW}^{-1} \cdot \mathrm{h}^{-1}$, respectively; Figure $3 \mathrm{~A}$ ). From Table 2 is clear that the greater difference is between the RED and BLUE light treatments, which is consistent with observations from changing nitrate concentration. In Figure 3B the interaction between species, $\mathrm{N}$ level and RED and BLUE spectra is reported. For the $8 \mathrm{mM} \mathrm{N}$ level, $D$. tenuifolia showed slightly higher NR activity for both spectra (Figure 3B). With the lower N level, BLUE light caused a higher NR activity in Eruca, while in Diplotaxis RED light showed a NR activity that was eightfold higher than that of BLUE light (Figure 3B).

\section{Glucosinolates}

Our results highlighted that the main discriminating factor in influencing the total GSLs concentrations were the species and their interactions with light treatment or nitrogen level (Table 2). The species influenced total GLSs content (Figure 4), but no significant effects on the accumulation of GSV, DGTB, GAL, GNT (refer to Table 2 for acronyms) were observed.

Light had different effect on total GLSs depending on the species. In E. sativa the blue light produced lower concentrations of total GLSs, but in D. tenuifolia this was not the case (Figure 4). Observing the values of the GLSs in the two species with the same $\mathrm{N}$ level, it is evident that in E. sativa the concentration of GSLs was always lower with respect to D. tenuifolia, with the 


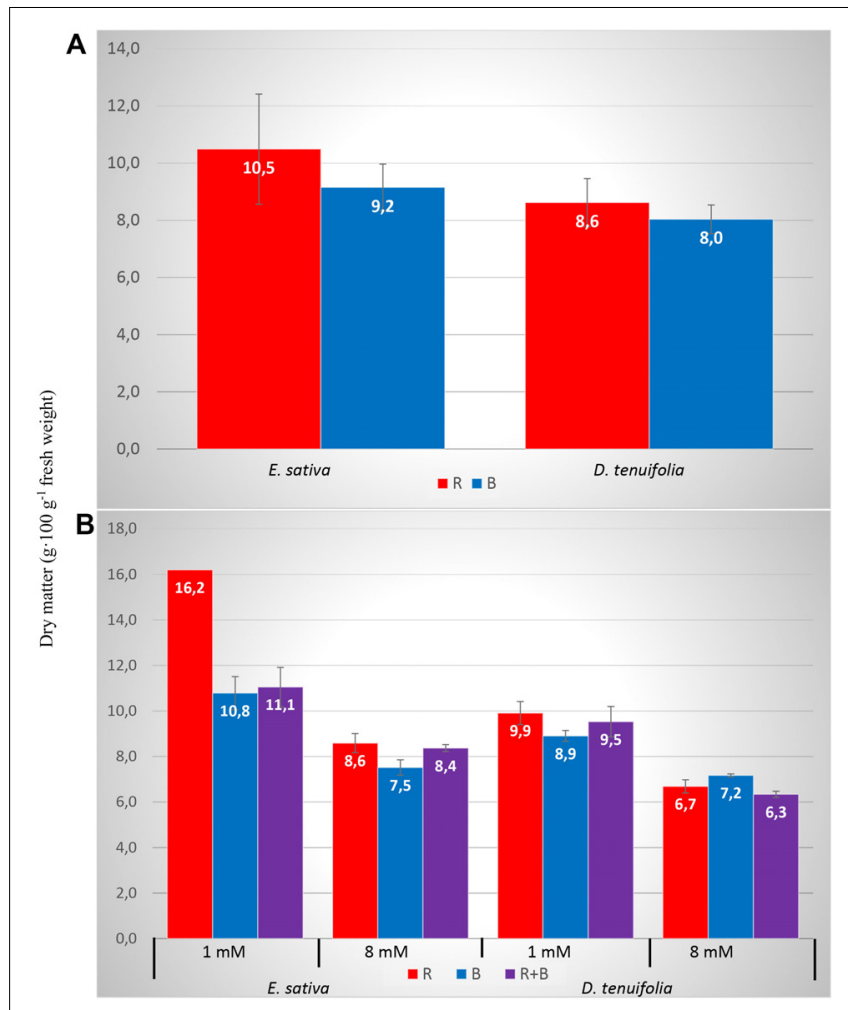

FIGURE 1 | Dry matter percentage of rocket leaves as influenced by interactions between species and light (A) and species, nitrogen level and light (B). Vertical bars represent the standard error.

exception of FS $8 \mathrm{M}$ and $\mathrm{R}+\mathrm{B} 8 \mathrm{mM}$ treatments (Figure 4). The lower total GLSs content was observed under the BLUE light, while the highest value was produced under the $\mathrm{R}+\mathrm{B}$ (1.28 and $6.75 \mathrm{mg} \cdot \mathrm{g} \mathrm{DW}^{-1}$, respectively - Figure 4). In D. tenuifolia, the BLUE light with $1 \mathrm{mM}$ of $\mathrm{N}$ produced a total content of GLSs that was only 56 and $61 \%$ if compared to the correspondent values and $\mathrm{N}$ concentration of FS and RED light, respectively (Figure 4).

Taking into account the interaction between the light and the nitrogen level, $D$. tenuifolia showed in general a higher content than Eruca. In particular, in Diplotaxis with $1 \mathrm{mM} \mathrm{N}$, the total GSL content was 3.4-folds higher than with $8 \mathrm{mM} \mathrm{N}$ - Figure 4) as opposed to E. sativa, in which the higher concentration was detected with $8 \mathrm{mM}$ treatment (Figure 4).

\section{DISCUSSION}

\section{Yield and Dry Matter (DM) Percentage}

The LED spectra showed a different behavior with respect to yield, as RED light produced a higher yield than $B$ and $R+B$ treatments (Tables 2, 3). This result agrees with those reported by Długosz-Grochowska et al. (2017) who found a higher yield in Valerianella locusta (L.) when red light was present, as red light is reported to be the most effective at activating photosynthesis (Kuno et al., 2017). In addition, Hogewoning et al. (2010) reported that an increases in the red light fraction are associated

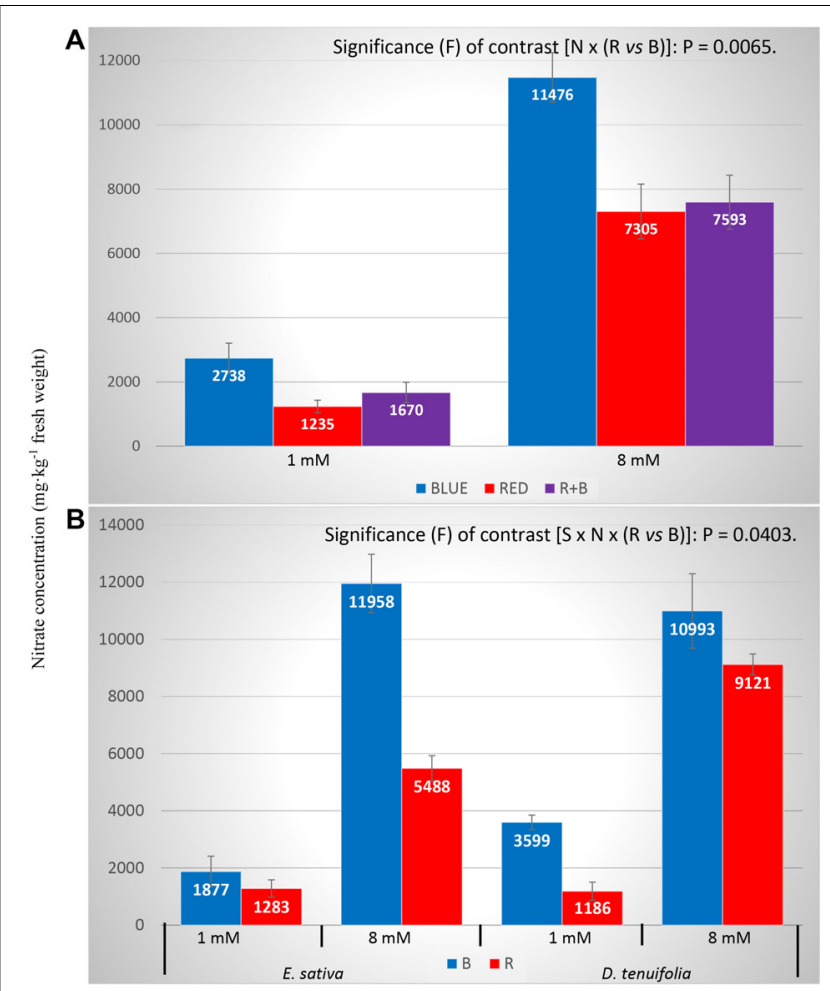

FIGURE 2 | Nitrates concentration of rocket leaves as influenced by interaction light $\times$ nitrogen level $\mathbf{( A )}$ and species $\times$ nitrogen level $\times$ light $(\mathbf{B})$. Vertical bars represent the standard error. S, species (E. sativa and D. tenuifolia); $\mathrm{N}$, nitrogen level into the nutrient solution (1 and $8 \mathrm{mM}$ ); $\mathrm{B}$, BLUE, peak at $460 \mathrm{~nm}$; R, RED, peak at $660 \mathrm{~nm}$.

with a simultaneous decrease in stomatal conductance, which has an inverse relationship with WUE. Yet, highest instantaneous photosynthesis under monochromatic red light did not always lead to optimal growth on the long run for certain crops such as cucumber (Hogewoning et al., 2010) or ornamentals (Zheng and Van Labeke, 2017). Our results thus indicate that rocket tolerates monochromatic red light regimes; probably because it is a fast growing, short cycling crop.

Similarly to yield, the DM percentage was not influenced by light, but it was dependant on species, nitrogen level, and interaction with some LED spectra. More in detail, DM was higher with $1 \mathrm{mM}$ level and in Eruca, but was modified by light treatment (Figures 1A,B). This result is due to the effect of the light on nitrate concentration in leaves. In fact, as reported by other studies on lettuce (Blom-Zandstra et al., 1988), the N level exerts an influence on the DM, since high nitrate concentrations derive from increased nitrogen availability, and is linked to a lower dry matter percentage. Nitrate accumulation causes an osmotic effect, which in turn decreases the dry matter content (Tei et al., 2000). The role of light spectra in increasing the DM percentage in leafy vegetables is still unclear: Lobiuc et al. (2017) have reported that DM of basil was significantly increased by an increasing intensity of blue light, while others (Ohashi-Kaneko et al., 2007; Wojciechowska et al., 2015) reported an increase of 


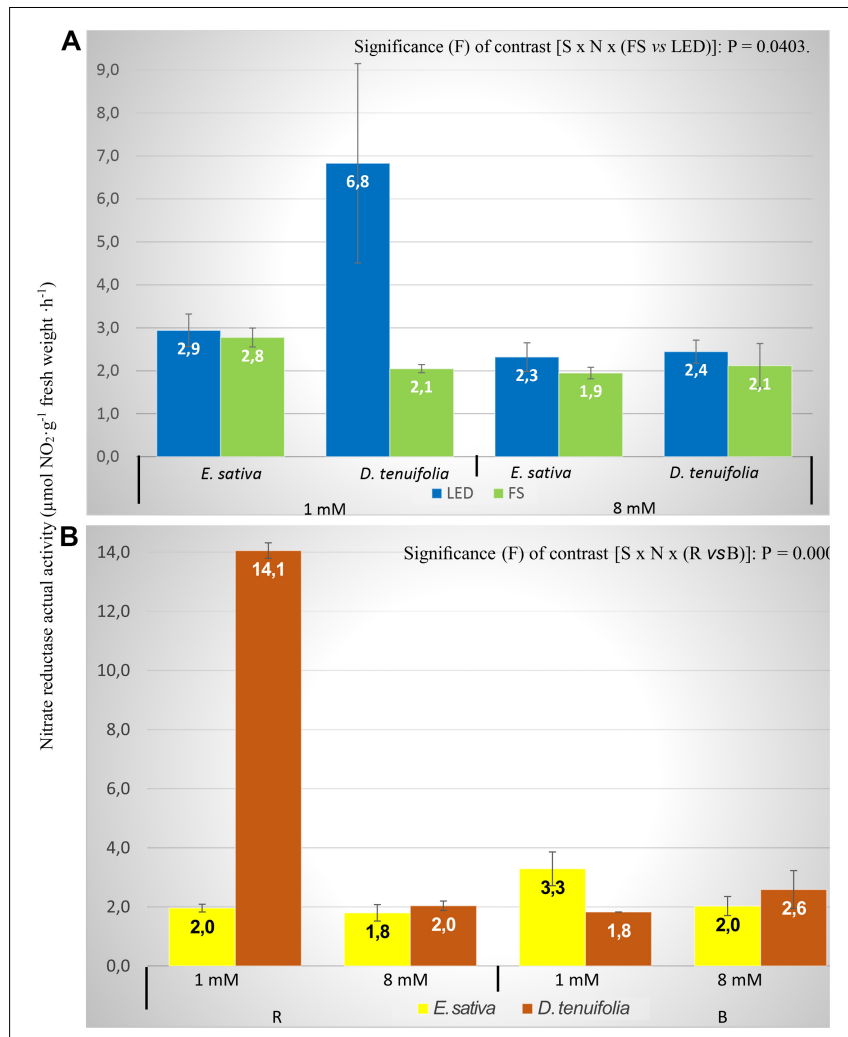

FIGURE 3 | Nitrate reductase actual activity (NRact) of rocket leaves in function of interactions species $\times$ nitrogen level $\times$ light $(\mathbf{A})$ and species $\times$ light spectrum (B). Vertical bars represent the standard error. S, species (E. sativa and $D$. tenuifolia); $\mathrm{N}$, nitrogen level into the nutrient solution (1 and $8 \mathrm{mM}) ; \mathrm{B}$, BLUE, peak at $460 \mathrm{~nm}$; R, RED.

DM in spinach, komatsuna and lamb's lettuce plants grown under red light. Response to light treatments is therefore likely to be highly species specific, and not universally applicable to all crops.

\section{Nitrate Concentrations}

The experiment took place at a relative low photon flux density $\left(150 \mu \mathrm{mol} \mathrm{m}^{-2} \mathrm{~s}^{-1}\right)$ favoring the accumulation of nitrate as an osmolyte in the vacuoles. At this light intensity, light spectra had a significant influence on $\mathrm{NO}_{3}{ }^{-}$concentration, and we observed some differences according with different spectra and $\mathrm{N}$ level; even if such differences were species dependant (Table 2 and Figures 2A,B).

Generally speaking, the concentration of $\mathrm{NO}_{3}{ }^{-}$in leaves increases with increasing nitrogen content in the growing media (Santamaria et al., 1997), even if this aspect may be affected by other parameters, such as light spectrum, species, and nutrient solution management (Gonnella et al., 2004). It is subject to dynamic changes in function of genetic and environmental factors (Anjana and Iqbal, 2007). The light spectrum has a prominent role in determining the $\mathrm{NO}_{3}{ }^{-}$concentration in leafy vegetables, and a lessening of nitrate concentration when supplementing plants with RED light. This has been reported by several authors in different species (Ohashi-Kaneko et al.,
2007; Urbonavièiute et al., 2007; Wojciechowska et al., 2016; Długosz-Grochowska et al., 2017). Such reduction is in line with the observation that the RED component of the light, which is effectively adsorbed by the phytochrome, may stimulate NR activity (Lillo, 2004). It is noteworthy from commercial point of view that, with the higher $\mathrm{N}$ concentration in the NS, the RED light in E. sativa had a $\mathrm{NO}_{3}{ }^{-}$concentration below the limits imposed by the Regulation (EC) N. 1258/2011 (5,488 mg.kg-1 of fresh weight), while in D. tenuifolia such limits were exceeded in both light treatments (Figure 2B). This is a fundamental finding, since the product with nitrate concentrations above the aforementioned limits cannot be legally sold on the market.

It is well known that genotypic variability influences nitrate concentrations (Anjana and Iqbal, 2007; Colonna et al., 2016), and that D. tenuifolia accumulates higher amounts than E. sativa (Santamaria et al., 2002). This difference may be explained by the difference in relative growth rate (RGR) between the two species. Ter Steege et al. (1999) reported that species with a high RGR [such as E. sativa - tends to have a faster growth rate as it is an annual species (Tripodi et al., 2017) - have a nitrate influx that may be $20-40 \%$ lower compared to species with lower RGR (in our case, D. tenuifolia, as it has a perennial behavior; Tripodi et al., 2017)]. However, nitrate accumulation in plants is a complex process, with main factors influencing nitrate accumulation that are mainly nutritional, environmental and physiological; as reported by Anjana and Iqbal (2009).

\section{Nitrate Reductase Activity}

The NR activity (both for $\mathrm{NR}_{\text {act }}$ and $\mathrm{NR}_{\text {total }}$ ) was significantly influenced by all the factors considered, and their interactions (Table 2 and Figures 3A,B), whilst the activation state was not affected by any parameters (Table 2). This is not surprising, since the activation state of NR is not always correlated with total NR activity in leaves (Man et al., 1999). In general, LED lights increased the NR activity, with the exception of E. sativa, with $1 \mathrm{mM}$ level of nitrogen (Figure 3A). The most remarkable difference was observed between RED and BLUE (Table 2) even if such difference was modulated by $\mathrm{N}$ concentration and species (Figure 3B). The importance of RED light in modulating the NR activity is well known, as the expression of NR is promoted by light absorbed by the phytochrome (Lillo, 2008). Therefore, the higher NR activity might be associated with the red spectrum that induces phytochrome phototransformations (Viršilë et al., 2018) that result in an increased synthesis of the enzyme, that is effectively mediated by phytochrome (Barro et al., 1989).

Typically, the activity of NR is driven by the concentration of nitrates in the substrate, so the higher their concentration, the higher the activity of NR. However, such activity is regulated by multiple parameters, such as light (including unconsidered spectra, such as green light wavelengths; Bian et al., 2018), temperature, salts, $\mathrm{CO}_{2}, \mathrm{pH}$, and substances that regulate growth (Kaiser and Huber, 1994; MacKintosh and Meek, 2001; Garg, 2013; Yanagisawa, 2014; Schoenbeck et al., 2015). Other factors, apart from nitrate, are also involved in the control of synthesis and degradation of NR (Man et al., 1999). With regard to the nitrate concentration, Chen et al. (2004) found that by increasing concentration in the substrate, the NR activity changed only 


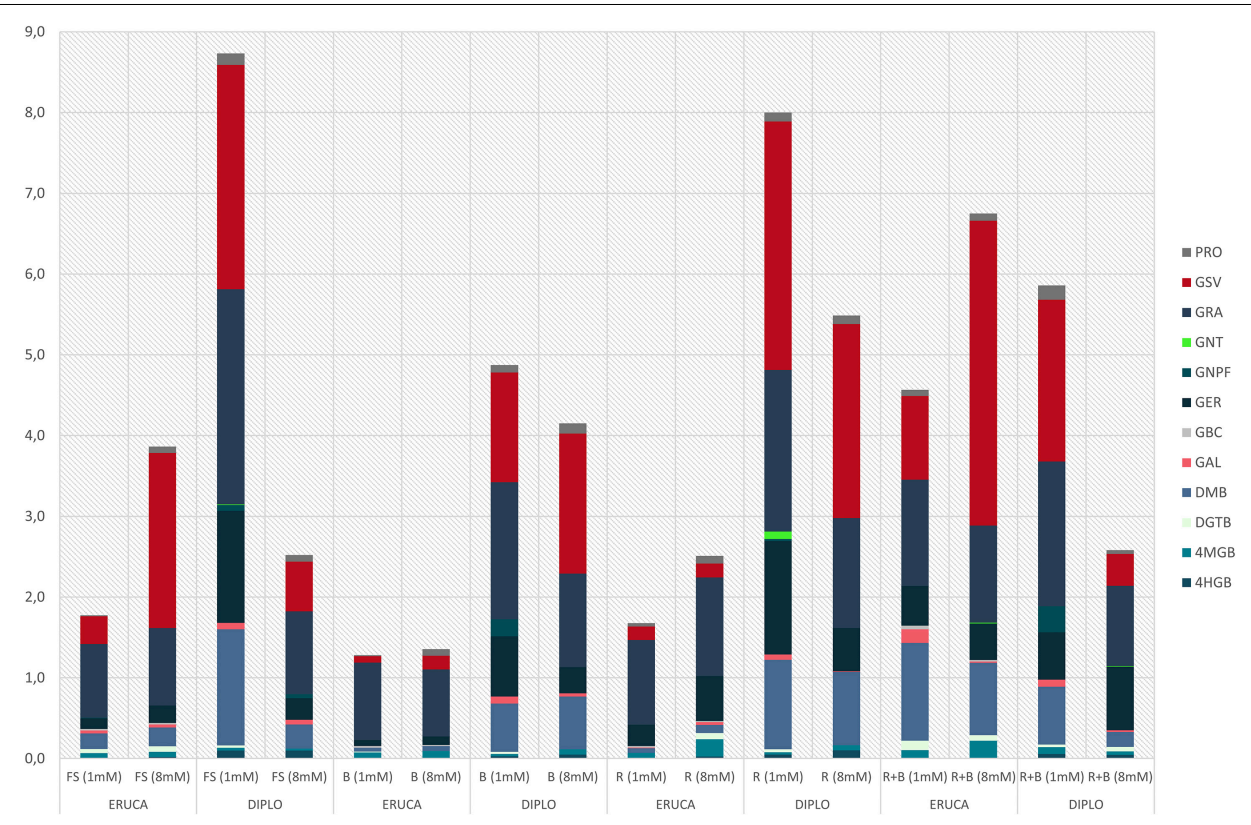

FIGURE 4 | GLSs content of rocket leaves (E. sativa and D. tenuifolia) in function of light and N level. (ERUCA, E. sativa; D, D. tenuifolia); 1 and 8 mM, nitrogen level into the nutrient solution; FS, full spectrum; B, BLUE, peak at $460 \mathrm{~nm}$; R, RED, peak at $660 \mathrm{~nm} ; \mathrm{R}+\mathrm{B}, \mathrm{RED}+\mathrm{BLUE}, 75 \% \mathrm{red}+25 \%$ blue. $4 \mathrm{HGB}$,

4-hydroxyglucobrassicin; 4MGB, 4-methoxyglucobrassicin; GBC, glucobrassicin; DMB, dimeric-glucosativin; GER, glucoerucin; GNPF, gluconapoleiferin; GRA, glucoraphanin; GSV, glucosativin; DGTB, diglucothiobeinin; PRO, progoitrin; GAL, glucoalyssin; GNT, gluconasturtiin.

when passing from the lowest concentration to the following level, and then stopped. This may imply that a threshold of nitrate concentration exists in the metabolic pool that regulates nitrate reductase activity (Chen et al., 2004). Conversely, Man et al. (1999) observed that in plants grown with low nitrate content, the NR activity was only $30 \%$ of the NR activity of plants with high nitrate content. However, in the former, the activation state of NR during the dark phase was almost double than that observed in light, thus compensating for the lower value of NR activity during the day.

\section{Glucosinolates}

The importance of GSLs and their concentrations in rocket is twofold: some compounds are responsible for the bitter taste and, secondly, the myrosinase breakdown products (mainly isothiocyanates; ITCs), have been demonstrated to be effective in preventing the risk of cardiovascular disease and some types of cancer (Bennett et al., 2007; Herr and Büchler, 2010; Melchini and Traka, 2010; Possenti et al., 2016), as well as producing characteristic pungency of Brassicaceae such as rocket (Bell et al., 2018).

The most important parameter that influenced GLS concentrations in our experiment was the species considered (Figure 4), but not for all individual glucosinolates (Table 2). However, the concentrations of total GSLs reported in the literature is highly variable; Pasini et al. (2012) and Di Gioia et al. (2018) found higher concentrations than those found in our experiments, while others Bell et al. (2015) reported total GLSs values closer to those found in the present experiment.
The species exerted an influence on the way the light spectra acted on GLSs concentration in the chosen cultivars: the blue light produced the lowest concentrations in E. sativa, but not in D. tenuifolia (Figure 4). Such results agree with Qian et al. (2016), who have observed in Chinese kale a decrease of total GSLs content when blue light was used. The final concentration of GSLs depends on not only the light treatment and the species, but also other parameters. For example, with respect to blue light, Kopsell and Sams (2013) found that blue light influenced positively total aliphatic GSLs concentrations. In our study no aliphatic GSL was influenced by the light alone (Table 2), but by an interaction between species and light (DMB and GSV) or species and N level (GNPF, GRA, GSV, and PRO - Table 2). The prominent role of the species in determining the GSL concentrations in our experiment may be inferred by observing the interactions between the experimental factors: where an interaction is present, the species always had a role, with the exception of 4MGB (Table 2).

It is noteworthy to mention that the concentration of total GSLs in rocket is not always unequivocally related to the species. In an experiment with 37 rocket salad accessions (both E. vesicaria and D. tenuifolia), Pasini et al. (2011) did not find any significant differences regarding the GSL content, while Di Gioia et al. (2018) reported a plant genotype influence. Variability is known to be high between individual accessions of each respective species (Bell et al., 2015) and so it is difficult to draw broad conclusions between the species based on these data alone. Such apparently inconsistent results are not unexpected, as GSL concentrations may vary as a function of several parameters, such as developmental stage, stress, plant 
age, photoperiod, temperature, and salinity (Hasegawa et al., 2000; Agerbirk et al., 2001; Coogan et al., 2001; Ahuja et al., 2010; Herr and Büchler, 2010) and geographical origin. These all have a significant effect on the profiles and concentrations of GSLs (Bennett et al., 2007). The crop environment exerts a great influence, i.e., if the cultivation has been done in field, controlled environment or with hydroponic systems (Bell et al., 2015) and it is well known that plant genotype and phenological stage of the final product (e.g., a completely developed leaf, sprouts or microgreens) all play important roles in determining the GSL content in plants (Padilla et al., 2007; Velasco et al., 2007; Wentzell and Kliebenstein, 2008; Francisco et al., 2011; PérezBalibrea et al., 2011; Agneta et al., 2014).

Nitrates and GSLs are key factors that determine the sensory and health-related quality of rocket crop and they are both localized in the plant vacuoles (Helmlinger et al., 1983). The concentration of GSLs depends also on the nitrogen form and concentration, since $\mathrm{NH}_{4}{ }^{+}$can decrease their concentration, while $\mathrm{NO}_{3}{ }^{-}$can significantly increase it (Kim and Ishii, 2006). The nitrogen level also influenced the total GLSs content jointly with light spectra: in D. tenuifolia RED and FS light, with $1 \mathrm{mM}$ of nitrogen, produced a total GLSs content 1.6- and 1.8-fold higher, respectively, than BLUE light at same $\mathrm{N}$ level. Such effects have been previously observed by Omirou et al. (2012), who reported that the biosynthesis of GLSs is influenced by N levels; even with an observed significant interaction with the sulfur level. Indeed, in our experiments the $S$ level into the nutrient solution was slightly higher in $1 \mathrm{mM}$ with respect to $8 \mathrm{mM}$ (76 vs. $29 \mathrm{mg} \cdot \mathrm{kg}^{-1}$, respectively), as in the $1 \mathrm{mM}$ treatment we added potassium in the form of $\mathrm{K}_{2} \mathrm{SO}_{4}$ - instead of $\mathrm{KNO}_{3}$, to reduce the $\mathrm{N}$ concentration to $1 \mathrm{mM}$ into the nutrient solution. Such results agree with those reported by De Pascale et al. (2008), who reported that in Brassicaceae species both yield and quality are strongly dependent on the $\mathrm{N}: \mathrm{S}$ ratio of the nutrient solution.

By considering the different classes of GSLs, aliphatics had a prominent role (Table 2), by representing 94.5 and $97.3 \%$ of the total for E. sativa and D. tenuifolia, respectively (Figure 4). In accordance with Omirou et al. (2012) who found that in E. sativa, the increase of the $\mathrm{N}$ supply, reduced most aliphatic GSLs and increased the indolic GSLs, in a similar manner to our findings. However, the influence of N on GSL concentrations is highly variable, and it has been reported that the increase of $\mathrm{N}$ level may reduce, increase, or have no effect on GSL concentration and composition, depending on the Brassicaceae species (Kim et al., 2002; Kopsell et al., 2007; Schonhof et al., 2007; Omirou et al., 2009).

\section{CONCLUSION}

The use of artificial lights is becoming more and more important in vegetable production; in particular in those environments with reduced solar radiation, such as in greenhouses and in Northern countries; especially during the autumn and winter period. Among the leafy vegetables, rocket (both E. sativa and D. tenuifolia) contain some interesting compounds for the benefit of human health, but may also accumulate high concentrations of nitrates in the leaves. Our results indicate that under low light levels, red light is able to reduce the nitrate concentration in leaves; and in particular by increasing the nitrate reductase activity. This reduction has been observed to be species and nitrogen fertilization dependent. The yield and dry matter are influenced primarily by nitrogen level, although red light increased yields with respect to blue and red + blue, up to a level similar to that of full spectrum.

Considering the total content of GSLs, in D. tenuifolia the red component of the light alone (or the FS, but only with $1 \mathrm{mM}$ of nitrogen) or mixed with blue (in E. sativa) increased their concentration. This indicates that each species may respond differently to light treatments and they should not be treated the same from a cultivation perspective. Such results are of interest to growers as they provide useful insights on the light spectra that should be used to improve the nutritional value of the rocket crop. Finally, the LED lights may be used in a real crop scenario, in both pre and post-harvest conditions, empowering growers and private companies to reduce nitrate concentration in rocket that may hamper the commercial sale of such product.

\section{DATA AVAILABILITY STATEMENT}

The datasets generated for this study are available on request to the corresponding author.

\section{AUTHOR CONTRIBUTIONS}

AS: substantial contributions to the conception or design of the work, drafting the work, final approval of the version, and nitrate reductase analysis. LB: glucosinolates analysis, interpretation of data, revised the article critically, and final approval of the version. PS: analysis and interpretation of data and final approval of the version. CW: glucosinolates analysis, interpretation of data, revised the article critically, and final approval of the version. M-CV: substantial contributions to the conception or design of the work, drafting the work, analysis and interpretation of data, and final approval of the version.

\section{FUNDING}

This research did not receive any specific grant from funding agencies in the public, commercial, or not-for-profit sectors with the following exception: LB was supported by a BBSRC Case Award (Reference BB/J012629/1).

\section{ACKNOWLEDGMENTS}

The authors would like to thank Christophe Petit for his help during the set up and ongoing of the experiments, to Dr. Britt Merlaen for her help and suggestions in the lab, to Mrs. Gerolmina Florio for nitrate analysis, and to Professor Małgorzata Reda for her valuable help regarding the setup of the protocol for the nitrate reductase activity determination. 


\section{REFERENCES}

Agerbirk, N., Olsen, C. E., and Nielsen, J. K. (2001). Seasonal variation in leaf glucosinolates and insect resistance in two types of Barbarea vulgaris ssp. arcuata. Phytochemistry 58, 91-100. doi: 10.1016/s0031-9422(01)00151-0

Agneta, R., Lelario, F., De Maria, S., Möllers, C., Bufo, S. A., and Rivelli, A. R. (2014). Glucosinolate profile and distribution among plant tissues and phenological stages of field-grown horseradish. Phytochemistry 106, 178-187. doi: 10.1016/j.phytochem.2014.06.019

Ahuja, I., de Vos, R. C. H., Bones, A. M., and Hall, R. D. (2010). Plant molecular stress responses face climate change. Trends Plant Sci. 15, 664-674. doi: 10. 1016/j.tplants.2010.08.002

Anjana, S. U., and Iqbal, M. (2007). Nitrate accumulation in plants, factors affecting the process, and human health implications. A review. Agron. Sustain. Dev. 27, 45-57. doi: 10.1051/agro:2006021

Anjana, S. U., and Iqbal, M. (2009). "Factors responsible for nitrate accumulation: a review," in Sustainable Agriculture, eds E. Lichtfouse, M. Navarrete, P. Debaeke, S. Véronique, and C. Alberola (Dordrecht: Springer Netherlands), 533-549. doi: 10.1007/978-90-481-2666-8_33

Ares, A. M., Nozal, M. J., Bernal, J. L., and Bernal, J. (2014). Optimized extraction, separation and quantification of twelve intact glucosinolates in broccoli leaves. Food Chem. 152, 66-74. doi: 10.1016/j.foodchem.2013.11.125

Ashworth, A., and Bescos, R. (2017). Dietary nitrate and blood pressure: evolution of a new nutrient? Nutr. Res. Rev. 30, 208-219. doi: 10.1017/ s0954422417000063

Barro, F., De La Haba, P., Maldonado, J. M., and Fontes, A. G. (1989). Effect of light quality on growth, contents of carbohydrates, protein and pigments, and nitrate reductase activity in soybean Plants. J. Plant Physiol. 134, 586-591. doi: 10.1016/S0176-1617(89)80152-X

Bell, L., Oloyede, O. O., Lignou, S., Wagstaff, C., and Methven, L. (2018). Taste and flavour perceptions of glucosinolates, isothiocyanates, and related compounds. Mol. Nut. Food Res. 62:e1700990.

Bell, L., Oruna-Concha, M. J., and Wagstaff, C. (2015). Identification and quantification of glucosinolate and flavonol compounds in rocket salad (Eruca sativa, Eruca vesicaria and Diplotaxis tenuifolia) by LC-MS: highlighting the potential for improving nutritional value of rocket crops. Food Chem. 172, 852-861. doi: 10.1016/j.foodchem.2014.09.116

Bell, L., and Wagstaff, C. (2014). Glucosinolates, myrosinase hydrolysis products, and flavonols found in rocket (Eruca sativa and Diplotaxis tenuifolia). J. Agric. Food Chem. 62, 4481-4492. doi: 10.1021/jf501096x

Bennett, R. N., Carvalho, R., Mellon, F. A., Eagles, J., and Rosa, E. A. S. (2007). Identification and quantification of glucosinolates in sprouts derived from seeds of wild Eruca sativa L. (Salad Rocket) and Diplotaxis tenuifolia L. (Wild Rocket) from diverse geographical locations. J. Agric. Food Chem. 55, 67-74. doi: $10.1021 /$ jf061997d

Bian, Z., Cheng, R., Wang, Y., Yang, Q., and Lu, C. (2018). Effect of green light on nitrate reduction and edible quality of hydroponically grown lettuce (Lactuca sativa L.) under short-term continuous light from red and blue lightemitting diodes. Environ. Exp. Bot. 153, 63-71. doi: 10.1016/j.envexpbot.2018. 05.010

Bianco, V. V. (1995). "Rocket, an ancient underutilized vegetable crop and its potential," in Rocket Genetic Resources Network: Report of the First Meeting, 1315 November, 1994, Lisbon, Portugal, ed. S. Padulosi (Rome: International Plant Genetic Resources Institute), 1-73.

Bianco, V. V., Boari, F., and Pezzuto, A. (1998). Effect of nitrogen and plant density on direct-seeded or transplanted wild rocket. Acta Hortic. 467, 277-286. doi: 10.17660/actahortic.1998.467.31

Björkman, M., Klingen, I., Birch, A. N. E., Bones, A. M., Bruce, T. J. A., Johansen, T. J., et al. (2011). Phytochemicals of Brassicaceae in plant protection and human health - influences of climate, environment and agronomic practice. Phytochemistry 72, 538-556. doi: 10.1016/j.phytochem.2011.01.014

Blom-Zandstra, M., Lampe, J. E. M., and Ammerlaan, F. H. M. (1988). C and $\mathrm{N}$ utilization of two lettuce genotypes during growth under non-varying light conditions and after changing the light intensity. Physiol. Plant. 74, 147-153. doi: 10.1111/j.1399-3054.1988.tb04955.x

Bondonno, C. P., Croft, K. D., and Hodgson, J. M. (2016). Dietary nitrate, nitric oxide, and cardiovascular health. Crit. Rev. Food Sci. Nutr. 56, 2036-2052. doi: $10.1080 / 10408398.2013 .811212$
Chen, B. M., Wang, Z. H., Li, S. X., Wang, G. X., Song, H. X., and Wang, X. N. (2004). Effects of nitrate supply on plant growth, nitrate accumulation, metabolic nitrate concentration and nitrate reductase activity in three leafy vegetables. Plant Sci. 167, 635-643. doi: 10.1016/j.plantsci.2004.05.015

Colonna, E., Rouphael, Y., Barbieri, G., and De Pascale, S. (2016). Nutritional quality of ten leafy vegetables harvested at two light intensities. Food Chem. 199, 702-710. doi: 10.1016/j.foodchem.2015.12.068

Coogan, R., Wills, R. B., and Nguyen, V. (2001). Pungency levels of white radish (Raphanus sativus L.) grown in different seasons in Australia. Food Chem. 72, 1-3. doi: 10.1016/s0308-8146(00)00164-3

D'Antuono, L. F., Elementi, S., and Neri, R. (2008). Glucosinolates in Diplotaxis and Eruca leaves: diversity, taxonomic relations and applied aspects. Phytochemistry 69, 187-199. doi: 10.1016/j.phytochem.2007.06.019

De Feo, V., and Senatore, F. (1993). Medicinal plants and phytotherapy in the Amalfitan Coast, Salerno Province, Campania, Southern Italy. J. Ethnopharmacol. 39, 39-51. doi: 10.1016/0378-8741(93)90049-b

De Pascale, S., Maggio, A., Orsini, F., Bottino, A., and Barbieri, G. (2008). Sulphur fertilisation affects yield and quality in friarielli (Brassica rapa L. subsp. sylvestris L. Janch. var. esculenta Hort.) grown in a floating system. J. Hortic. Sci. Biotechnol. 83, 743-748. doi: 10.1080/14620316.2008.11512454

Di Gioia, F., Avato, P., Serio, F., and Argentieri, M. P. (2018). Glucosinolate profile of Eruca sativa, Diplotaxis tenuifolia and Diplotaxis erucoides grown in soil and soilless systems. J. Food Compos. Anal. 69, 197-204. doi: 10.1016/j.jfca.2018. 01.022

Długosz-Grochowska, O., Wojciechowska, R., Kruczek, M., and Habela, A. (2017). Supplemental lighting with LEDs improves the biochemical composition of two Valerianella locusta (L.) cultivars. Hortic. Environ. Biotechnol. 58, 441-449. doi: 10.1007/s13580-017-0300-4

Dunn, W. B., Wilson, I. D., Nicholls, A. W., and Broadhurst, D. (2012). The importance of experimental design and QC samples in large-scale and MSdriven untargeted metabolomic studies of humans. Bioanalysis 4, 2249-2264. doi: 10.4155/bio.12.204

Egea-Gilabert, C., Fernández, J. A., Migliaro, D., Martínez-Sánchez, J. J., and Vicente, M. J. (2009). Genetic variability in wild vs. cultivated Eruca vesicaria populations as assessed by morphological, agronomical and molecular analyses. Sci. Hortic. (Amsterdam) 121, 260-266. doi: 10.1016/j.scienta.2009. 02.020

European Commission (2011). COMMISSION REGULATION (EU) No 1258/2011 of 2 December 2011 Amending Regulation (EC) No 1881/2006 as Regards Maximum Levels for Nitrates in Foodstuffs. Brussels: European Commission.

European Food Safety Authority (2008). Nitrate in vegetables - scientific opinion of the panel on contaminants in the food chain. EFSA J. 689, 1-79.

Francisco, M., Cartea, M. E. M. E., Soengas, P., and Velasco, P. (2011). Effect of genotype and environmental conditions on health-promoting compounds in Brassica rapa. J. Agric. Food Chem. 59, 2421-2431. doi: 10.1021/jf103492r

Garg, S. K. (2013). Role and hormonal regulation of nitrate reductase activity in higher plants: a review. Plant Sci. Feed 3, 13-20.

Gonnella, M., Serio, F., Conversa, G., and Santamaria, P. (2004). Production and nitrate content in Lamb's lettuce grown in floating system. Acta Hortic. 644, 61-68. doi: 10.17660/actahortic.2004.644.5

Hall, M., Jobling, J., and Rogers, G. (2012). Some perspectives on rocket as a vegetable crop: a review. Veg. Crop. Res. Bull. 76, 21-41.

Hasegawa, T., Yamada, K., Kosemura, S., Yamamura, S., and Hasegawa, K. (2000). Phototropic stimulation induces the conversion of glucosinolate to phototropism-regulating substances of radish hypocotyls. Phytochemistry 54, 275-279. doi: 10.1016/s0031-9422(00)00080-7

Helmlinger, J., Rausch, T., and Hilgenberg, W. (1983). Localization of newly synthesized indoIe-3-methylglucosinolate (= glucobrassicin) in vacuoles from horseradish (Armoracia rusticana). Physiol. Plant. 58, 302-310. doi: 10. 1111/j.1399-3054.1983.tb04185.x

Herr, I., and Büchler, M. W. (2010). Dietary constituents of broccoli and other cruciferous vegetables: implications for prevention and therapy of cancer. Cancer Treat. Rev. 36, 377-383. doi: 10.1016/j.ctrv.2010.01.002

Hogewoning, S. W., Trouwborst, G., Maljaars, H., Poorter, H., van Ieperen, W., and Harbinson, J. (2010). Blue light dose-responses of leaf photosynthesis morphology, and chemical composition of Cucumis sativus grown under different combinations of red and blue light. J. Exp. Bot. 61, 3107-3117. doi: $10.1093 /$ jxb/erq132 
Jin, J., Koroleva, O. A., Gibson, T., Swanston, J., Maganj, J., Zhang, Y. A. N., et al. (2009). Analysis of phytochemical composition and chemoprotective capacity of rocket (Eruca sativa and Diplotaxis tenuifolia) leafy salad following cultivation in different environments. J. Agric. Food Chem. 57, 5227-5234. doi: 10.1021/jf9002973

Jonvic, K. L., Jean, N., Pinckaers, P. J., Senden, J. M., van Loon, L. J., Verdijk, L. B., et al. (2016). Nitrate-rich vegetables increase plasma nitrate and nitrite concentrations and lower blood pressure in healthy adults. J. Nutr. 146, 986993. doi: 10.3945/jn.116.229807

Kaiser, W. M., and Huber, S. C. (1994). Posttranslational regulation of nitrate reductase in higher-plants. Plant Physiol. 106, 817-821. doi: 10.1104/pp.106. 3.817

Kim, S. J., and Ishii, G. (2006). Glucosinolate profiles in the seeds, leaves and roots of rocket salad (Eruca sativa Mill.) and anti-oxidative activities of intact plant powder and purified 4-methoxyglucobrassicin. Soil Sci. Plant Nutr. 52, 394-400. doi: $10.1111 /$ j.1747-0765.2006.00049.x

Kim, S.-J., Matsuo, T., Watanabe, M., and Watanabe, Y. (2002). Effect of nitrogen and sulphur application on the glucosinolate content in vegetable turnip rape (Brassica rapa L.). Soil Sci. Plant Nutr. 48, 43-49. doi: 10.1080/00380768.2002. 10409169

Kopsell, D. A., Barickman, T. C., Sams, C. E., and McElroy, J. S. (2007). Influence of nitrogen and sulfur on biomass production and carotenoid and glucosinolate concentrations in watercress (Nasturtium officinale R. Br.). J. Agric. Food Chem. 55, 10628-10634. doi: 10.1021/jf072793f

Kopsell, D. A., and Sams, C. E. (2013). Increases in shoot tissue pigments, glucosinolates, and mineral elements in sprouting broccoli after exposure to short-duration blue light from light emitting diodes. J. Am. Soc. Hortic. Sci. 138, 31-37. doi: 10.21273/jashs.138.1.31

Kuno, Y., Shimizu, H., Nakashima, H., Miyasaka, J., and Ohdoi, K. (2017). Effects of irradiation patterns and light quality of red and blue light-emitting diodes on growth of leaf lettuce (Lactuca sativa L. "Greenwave"). Environ. Control Biol. 55, 129-135. doi: 10.2525/ecb.55.129

Lelario, F., Bianco, G., Bufo, S. A., and Cataldi, T. R. I. (2012). Establishing the occurrence of major and minor glucosinolates in Brassicaceae by LCESI-hybrid linear ion-trap and Fourier-transform ion cyclotron resonance mass spectrometry. Phytochemistry 73, 74-83. doi: 10.1016/j.phytochem.2011. 09.010

Lillo, C. (2004). "Light regulation of nitrate uptake, assimilation and metabolism," in Nitrogen Acquisition and Assimilation in Higher Plants. Plant Ecophysiology, Vol. 3, eds S. Amâncio and I. Stulen (Dordrecht: Springer), 149-184. doi: 10.1007/978-1-4020-2728-4_6

Lillo, C. (2008). Signalling cascades integrating light-enhanced nitrate metabolism. Biochem. J. 415, 11-19. doi: 10.1042/BJ20081115

Lobiuc, A., Vasilache, V., Oroian, M., Stoleru, T., Burducea, M., Pintilie, O., et al. (2017). Blue and Red LED illumination improves growth and bioactive compounds contents in acyanic and cyanic Ocimum basilicum L. Microgreens. Molecules 22:2111. doi: 10.3390/molecules22122111

MacKintosh, C., and Meek, S. E. M. (2001). Regulation of plant NR activity by reversible phosphorylation, 14-3-3 proteins and proteolysis. Cell. Mol. Life Sci. 58, 205-214. doi: 10.1007/pl00000848

Mahran, G. H., Kadry, H. A., Isaac, Z. G., Thabet, C. K., Al-Azizi, M. M., and ElOlemy, M. M. (1991). ). Investigation of diuretic drug plants. 1. Phytochemical screening and pharmacological evaluation of Anethum graveolens L., Apium graveolens L., Daucus carota L. and Eruca sativa Mill. Phyther. Res. 5, 169-172. doi: $10.1002 /$ ptr.2650050406

Man, H. M., Abd-El Baki, G. K., Stegmann, P., Weiner, H., and Kaiser, W. M. (1999). The activation state of nitrate reductase is not always correlated with total nitrate reductase activity in leaves. Planta 209, 462-468. doi: 10.1007/ s004250050749

Melchini, A., and Traka, M. (2010). Biological profile of erucin: a new promising anticancer agent from cruciferous vegetables. Toxins (Basel) 2, 593-612. doi: 10.3390/toxins 2040593

Ohashi-Kaneko, K., Takase, M., Kon, N., Fujiwara, K., and Kurata, K. (2007). Effect of light quality on growth and vegetable quality in leaf lettuce, spinach and komatsuna. Environ. Control Biol. 45, 189-198. doi: 10.2525/ecb.45.189

Omirou, M., Papastefanou, C., Katsarou, D., Papastylianou, I., Passam, H. C., Ehaliotis, C., et al. (2012). Relationships between nitrogen, dry matter accumulation and glucosinolates in Eruca sativa Mill. The applicability of the critical NO 3-N levels approach. Plant Soil 354, 347-358. doi: 10.1007/s11104011-1071-9

Omirou, M. D., Papadopoulou, K. K., Papastylianou, I., Constantinou, M., Karpouzas, D. G., Asimakopoulos, I., et al. (2009). Impact of nitrogen and sulfur fertilization on the composition of glucosinolates in relation to sulfur assimilation in different plant organs of broccoli. J. Agric. Food Chem. 57, 9408-9417. doi: 10.1021/jf901440n

Ouzounis, T., Rosenqvist, E., and Ottosen, C.-O. (2015). Spectral effects of artificial light on plant physiology and secondary metabolism: a review. HortScience 50, 1128-1135. doi: 10.21273/hortsci.50.8.1128

Padilla, G., Cartea, M. E., Velasco, P., de Haro, A., and Ordás, A. (2007). Variation of glucosinolates in vegetable crops of Brassica rapa. Phytochemistry 68, 536545. doi: 10.1016/j.phytochem.2006.11.017

Pasini, F., Verardo, V., Caboni, M. F., and D'Antuono, L. F. (2012). Determination of glucosinolates and phenolic compounds in rocket salad by HPLC-DAD-MS: Evaluation of Eruca sativa Mill. and Diplotaxis tenuifolia L. genetic resources. Food Chem. 133, 1025-1033. doi: 10.1016/j.foodchem.2012.01.021

Pasini, F., Verardo, V., Cerretani, L., Caboni, M. F., and D'Antuono, L. F. (2011). Rocket salad (Diplotaxis and Eruca spp.) sensory analysis and relation with glucosinolate and phenolic content. J. Sci. Food Agric. 91, 2858-2864. doi: $10.1002 /$ jsfa. 4535

Pérez-Balibrea, S., Moreno, D. A., and García-Viguera, C. (2011). Genotypic effects on the phytochemical quality of seeds and sprouts from commercial broccoli cultivars. Food Chem. 125, 348-354. doi: 10.1016/j.foodchem.2010.09.004

Porcelli, S., Pugliese, L., Rejc, E., Pavei, G., Bonato, M., Montorsi, M., et al. (2016). Effects of a short-term high-nitrate diet on exercise performance. Nutrients 8:534. doi: 10.3390/nu8090534

Possenti, M., Baima, S., Raffo, A., Durazzo, A., Giusti, A. M., and Natella, F. (2016). "Glucosinolates in food," in Glucosinolates, eds J.-M. Mérillon and K. G. Ramawat (Cham: Springer International Publishing), 1-46. doi: 10.1007/9783-319-26479-0_4-1

Premuzic, Z., Gárate, A., and Bonilla, I. (2002). Production of lettuce under different fertilisation treatments, yield and quality. Acta Hortic. 571, 65-72. doi: 10.17660/actahortic.2002.571.6

Qian, H., Liu, T., Deng, M., Miao, H., Cai, C., Shen, W., et al. (2016). Effects of light quality on main health-promoting compounds and antioxidant capacity of Chinese kale sprouts. Food Chem. 196, 1232-1238. doi: 10.1016/j.foodchem. 2015.10.055

Reda, M. (2015). Response of nitrate reductase activity and NIA genes expression in roots of Arabidopsis hxk1 mutant treated with selected carbon and nitrogen metabolites. Plant Sci. 230, 51-58. doi: 10.1016/j.plantsci.2014.10.008

Santamaria, P. (2006). Nitrate in vegetables: toxicity, content, intake and EC regulation. J. Sci. Food Agric. 86, 10-17. doi: 10.1002/jsfa.2351

Santamaria, P., Elia, A., and Gonnella, M. (1997). Changes in nitrate accumulation and growth of endive plants during light period as affected by nitrogen level and form. J. Plant Nutr. 20, 1255-1266. doi: 10.1080/01904169709365333

Santamaria, P., Elia, A., Papa, G., and Serio, F. (1998a). Nitrate and ammonium nutrition in chicory and rocket salad plants. J. Plant Nutr. 21, 1779-1789. doi: 10.1080/01904169809365523

Santamaria, P., Elia, A., Parente, A., and Serio, F. (1998b). Fertilization strategies for lowering nitrate content in leafy vegetables: chicory and rocket salad cases. J. Plant Nutr. 21, 1791-1803. doi: 10.1080/01904169809365524

Santamaria, P., Elia, A., and Serio, F. (2002). Effect of solution nitrogen concentration on yield, leaf element content, and water and nitrogen use efficiency of three hydroponically-grown rocket salad genotypes. J. Plant Nutr. 25, 245-258. doi: 10.1081/pln-100108833

Schoenbeck, M. A., Mccormick, M. F., Kellner, T. D., and Rauter, C. M. (2015). Light suppression of nitrate reductase activity in seedling and young plant tissue. Trans. Nebraska Acad. Sci. 35, 41-52.

Schonhof, I., Blankenburg, D., Müller, S., and Krumbein, A. (2007). Sulfur and nitrogen supply influence growth, product appearance, and glucosinolate concentration of broccoli. J. Plant Nutr. Soil Sci. 170, 65-72. doi: 10.1002/jpln. 200620639

Seginer, I. (2003). A dynamic model for nitrogen-stressed lettuce. Ann. Bot. 91, 623-635. doi: 10.1093/aob/mcg069

Signore, A., Santamaria, P., and Serio, F. (2008). Influence of salinity source on production, quality, and environmental impact of tomato grown in a soilless closed system. J. Food Agric. Environ. 6, 357-361. 
Steel, R. G., and Torrie, J. H. (1988). Biostatistics: Principles and Procedures. México: McGraw Hill.

Tei, F., Benincasa, P., and Guiducci, M. (2000). Effect of nitrogen availability on growth and nitrogen uptake in lettuce. Acta Hortic. 533, 385-392. doi: 10.17660/actahortic.2000.533.47

Ter Steege, M. W., Stulen, I., Wiersema, P. K., Posthumus, F., and Vaalburg, W. (1999). Efficiency of nitrate uptake in spinach: impact of external nitrate concentration and relative growth rate on nitrate influx and efflux. Plant Soil 208, 125-134.

Tripodi, P., Francese, G., and Mennella, G. (2017). Rocket salad: crop description, bioactive compounds and breeding perspectives. Adv. Hortic. Sci. 31, 107-113.

Urbonavièiute, A., Pinho, P., Samuoliene, G., Duchovskis, P., Vitta, P., Stonkus, G., et al. (2007). Effect of short-wavelength light on lettuce growth and nutritional quality. Sci. Work. Lith. Inst. Hortic. Lith. Univ. Agric. 26, 157-165.

Velasco, P., Cartea, M. E., González, C., Vilar, M., and Ordás, A. (2007). Factors affecting the glucosinolate content of kale (Brassica oleracea acephala Group). J. Agric. Food Chem. 55, 955-962. doi: 10.1021/jf0624897

Viršilë, A., Brazaitytë, A., Sakalauskienë, S., Jankauskienë, J., Miliauskienë, J., and Vaštakaitë, V. (2018). LED lighting for reduced nitrate contents in green vegetables. Acta Hortic. 1227, 669-676. doi: 10.17660/ActaHortic.2018.1227.85

Viršilë, A., Brazaitytë, A., Vaštakaitë-Kairienë, V., Jankauskienë, J., Miliauskienë, J., Samuolienë, G., et al. (2019). Nitrate, nitrite, protein, amino acid contents, and photosynthetic and growth characteristics of tatsoi cultivated under various photon flux densities and spectral light compositions. Sci. Hortic. (Amsterdam) 258:108781. doi: 10.1016/j.scienta.2019.108781

Viršilë, A., Brazaitytë, A., Vaštakaitë-Kairienë, V., Miliauskienë, J., Jankauskienë, J., Novièkovas, A., et al. (2020). The distinct impact of multi-color LED light on nitrate, amino acid, soluble sugar and organic acid contents in red and green leaf lettuce cultivated in controlled environment. Food Chem. 310:125799. doi: 10.1016/j.foodchem.2019.125799

Weightman, R. M., Huckle, A. J., Roques, S. E., Ginsburg, D., and Dyer, C. J. (2012). Factors influencing tissue nitrate concentration in field-grown wild rocket (Diplotaxis tenuifolia) in southern England. Food Addit. Contam. Part A Chem. Anal. Control. Expo. Risk Assess. 29, 1425-1435. doi: 10.1080/19440049. 2012.696215

Wentzell, A. M., and Kliebenstein, D. J. (2008). Genotype, age, tissue, and environment regulate the structural outcome of glucosinolate activation. Plant Physiol. 147, 415-428. doi: 10.1104/pp.107.115279

Wojciechowska, R., Dugosz-Grochowska, O., Koton, A., Zupnik, M., DługoszGrochowska, O., Kołton, A., et al. (2015). Effects of LED supplemental lighting on yield and some quality parameters of lamb's lettuce grown in two winter cycles. Sci. Hortic. (Amsterdam) 187, 80-86. doi: 10.1016/j.scienta.2015.03.006

Wojciechowska, R., Kołton, A., Długosz-Grochowska, O., and Knop, E. (2016). Nitrate content in Valerianella locusta L. plants is affected by supplemental LED lighting. Sci. Hortic. (Amsterdam) 211, 179-186. doi: 10.1016/j.scienta.2016. 08.021

Yanagisawa, S. (2014). Transcription factors involved in controlling the expression of nitrate reductase genes in higher plants. Plant Sci. 229, 167-171. doi: 10. 1016/j.plantsci.2014.09.006

Zheng, L., and Van Labeke, M.-C. (2017). Long-term effects of red- and bluelight emitting diodes on leaf anatomy and photosynthetic efficiency of three ornamental pot plants. Front. Plant Sci. 8:917. doi: 10.3389/fpls.2017.00917

Conflict of Interest: The authors declare that the research was conducted in the absence of any commercial or financial relationships that could be construed as a potential conflict of interest.

Copyright (c) 2020 Signore, Bell, Santamaria, Wagstaff and Van Labeke. This is an open-access article distributed under the terms of the Creative Commons Attribution License (CC BY). The use, distribution or reproduction in other forums is permitted, provided the original author(s) and the copyright owner(s) are credited and that the original publication in this journal is cited, in accordance with accepted academic practice. No use, distribution or reproduction is permitted which does not comply with these terms. 